\title{
ANALISIS SEMANTIK KATA ZAWJ DALAM AL-QUR'AN
}

\author{
Marjiatun Hujaz \\ atun_9d_30@yahoo.co.id \\ Ponpes Al-Anwar 3 Putri \\ Nur Huda \\ nurhuda@staialanwar.ac.id \\ STAI Al-Anwar Sarang-Rembang \\ Syihabudin Qalyubi \\ syihabuddin.qalyubi@uin-suka.ac.id \\ UIN Sunan Kalijaga Yogyakarta
}

\begin{abstract}
This study aims to examines the meaning of zawj in al-Qur'an. This research is a qualitative research using descriptive-analysis method. Descriptive-analysis method aims to analyze the zawj' word in the Qur'an. The meaning of zawj in the Qur'an is very vareative. In the Koran with various derivations, the word zawj is 21 derivations contained in 72 verses of 43 surahs and is mentioned in 81 times. The researcher used the semantic analysis of al-Qur'an which was initiated by Toshihiko Izutsu who tried to address the world view of Qu'ran (weltanschauung) through semantic analysis of the vocabulary and key terms in the Qur'an. This research concludes that the basic meaning of the word zawj is something that is not singular or something that has an equivalent. Zawj can be interpreted as: a husband in the surah (al-Mujādalah [58]: 1; wife in the surah (al-Baqarah [2]: 35; a partner, namely Allah created all beings in pairs (az-Dzariyat [51]: 49;animals are male and female pairs (al-An'ām [6]: 143), plants (al-Syu'arā [367]: 7); and groups (al-Wāqi'ah [56]: 7. In the preQur'anic, the word zawj is defined as a rug. In the Qur'anic period it is divided into two, namely Mecca and Medina. The Mecca period has a close meaning with the sign of the greatness of Allah and the pleasure that Allah gives. The Medina period contains the laws of separation. In the post-Qur'anic period, the word zawj describes gender equality, that men and women are the same components without being differentiated, so that there is a harmonious life in pairs.
\end{abstract}

Keywords :Diachronic, Izutsu,Semantic, Synchronic, Zawj.

Abstrak
Penelitian ini bertujuan untuk menganalisis makna zawj dalam al-Qur'an.
Penelitian ini merupakan penelitian kualitatif dengan menggunakan metode
deskriptif analitis. Metode deskriptif analitisdigunakan untuk menganalisis
kata zawj dalam al-Qur'an. Makna dasar zawj di dalam al-Qur'an variatif. Di
dalam al-Qur'an dengan berbagai derivasi, kata zawj berjumlah 21 yang
termuat dalam 72 ayat dari 43 surah dan disebutkan dalam 81 kali. Peneliti
menggunakan analisa semantik al-Qur'an Toshihiko Izutsu yang berusaha
menyikap pandangan dunia al-Qu'ran (weltanschauung) melalui analisis
terhadap kosakata dan istilah kunci dalam al-Quran. Penelitian ini
menyimpulkan bahwa makna dasar kata zawjadalah sesuatu yang bukan


tunggal atau sesuatu yang memiliki padanan.Zawj bisa diartikan sebagai: suami seperti dalam surat al-Mujādalah [58]:1; istri dalam surat al-Baqarah [2]:35; pasangan yaitu Allah menciptakan semua makhluk berpasang-pasangan (az-Dzariyat [51]:49); hewan yaitu pasangan jantan dan betina (al-An'ām [6]:143); tumbuhan (asy-Syu'arā [367]:7); dan golongan (al-Wāqi'ah [56]:7). Pada periode pra Qur'anik, kata zawj memiliki makna permadani. Pada periode Qur'anik terbagi menjadi dua, yaitu Makkah dan Madinah. Periode Makkah memiliki makna yang erat dengan tanda kebesaran Allah dan kenikmatan yang Allah berikan. Periode Madinah terkait tentang hukum-hukum keberpasangan. Pada masa pasca Qur'anik kata zawjmenggambarkan tentang kesetaraan gender, bahwa laki-laki dan perempuan merupakan komponen yang sama tanpa dibedakan, sehingga bisa tercapai keberlangsungan hidup yang harmonis dalam keberpasangan.

Kata Kunci : Diakronik, Izutsu,Semantik, Sinkronik, Zawj.

\section{A. Pendahuluan}

Sudah menjadi rahasia umum bahwa al-Qur'an merupakan kitab suci yang diturunkan kepada nabi Muhammad dengan menggunakan media bahasa Arab. Hal tersebut terekam dengan jelas dalam al-Qur'an bahwa bahasa yang digunakan adalah bahasa Arab ${ }^{1}$. Sehingga, untuk bisa memahami makna dan isi al-Qur'an, langkah pertama dan tidak bisa dipungkiri adalah penguasaan bahasa Arab.

Amin al-Khūllī menegaskan bahwa pendekatan bahasa dan sastra (baca : bahasa dan sastra Arab) merupakan langkah awal yang harus ditempuh oleh peneliti jika ingin memahami al-Qur'an secara mendalam, baru kemudian melangkah ke pendekatan-pendekatan lain, seperti sejarah, psikologi, sains, sosial, dan lainnya ${ }^{2}$. Alasan paling mendasar adalah karena al-Qur'an diturunkan menggunakan bahasa Arab. Sehingga kajian kebahasaan dan kesusatraan (Arab) menjadi sangat urgen untuk memahami dan mendalami makna dan isi alQur'an.

Salah satu pendekatan linguistik yang digunakan untuk memahami al-Qur'am adalah pendekatan semantik. Secara umum, semantik merupakan ilmu bahasa atau kajian kebahasaan yang membahas tentang makna baik dalam tataran analisis fonologi, morfologi, maupun sintaksis ${ }^{3}$. Semantik yang dalam linguistik Arab dikenal dengan sebutan dalālah memiliki dua

\footnotetext{
${ }^{1}$ Lihat QS. Yūsuf [12]:2, QS. Ar-Ra'd [13]:37, QS. An-Naḥl [16]: 103, QS. Țāha [20]: 113, QS. Asy-Syu'arā' [26]: 195, QS. Az-Zumar [39]: 28, QS. Fușșilat [41]: 3 dan 44, QS. Asy-Syūra [42]: 7, QS. Az-Zukhruf [43]: 3, dan QS. Al-Ahqā̄f [46]: 12.

${ }^{2}$ Syafaatun Almirzanah, Pemikiran Hermeneutika Dalam Tradisi Islam: Reader (Yogyakarta: Universitas Islam Negeri Sunan Kalijaga, 2011). hlm. 231.

${ }^{3}$ Ahmad Mujahid, 'Makna Sinkronik-Diakronik Kata ‘Usr Dan Yusr Dalam Surat Al-Insyirāh', Relegia Jurnal Ilти-Ilmu Keislaman, 22.1 (2019), hlm. 97-114.
} 
Analisis Semantik Kata Zawj dalam Al-Qur'an Marijatun Hujaz, Nur Huda, dan Syihabuddin Qalyubi

Doi: doi.org/10.47454/itqan.v4i2.684

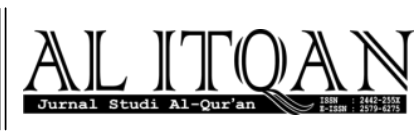

komponen yang tidak bisa dipisahkan sebagaimana dikatakan oleh Ferdinand de Saussure, pakar bahasa dari Swiss. Kedua komponan itu masing-masing adalah penanda (signifiant/الدال) dan petanda (signified/المدلول) Dalam hal ini, penanda bisa diartikan sebagai sesuatu yang mengartikan yang berbentuk bunyi bahasa, sementara petanda diartikan sebagai makna dari penanda.Salah satu tokoh yang menawarkan pendekatan semantik al-Qur'an adalah Toshihiko Izutsu, pakar bahasa sekaligus ilmuan besar yang berasal dari Jepang.

Tulisan ini secara analisis akan membahas bagaimana al-Qur'an memaknai kata zawj dari aspek gramatikal semantik. Pemilihan semantik Izutsu didasari karena mekanisme semantiknya mencakup bahasa pada setiap makna dasar dan relasional dengan menggunakan analisis sintagmatik dan paradigmatik. Sementara persoalan kronologi sejarah linguistiknya akan terlihat pada masa pra-Qur'anik, Qur'anik, dan pasca-Qur'anik. Sehingga akan diperoleh pemahaman yang komprehensif dan utuh tentang makna zawj dalam al-Qur'an.

\section{B. Selayang Pandang Semantik Toshihiko Izutsu}

Toshihiko Izutsu merupakan salah satu sarjana dan juga orientalis yang memiliki gagasan metode semantik dalam kajian al-Qur'an. Ia menyatakan bahwa semantik bukanlah analisis sederhana terhadap struktur bentuk kata atau kajian terhadap makna dasar yang melekat pada bentuk kata tersebut, akan tetapi -yang lebih signifikan- adalah sebuah kajian analitik terhadap istilah-istilah kunci suatu bahasa dengan suatu pandangan yang sampai pada pengertian konseptual weltanschauung atau -dengan istilah lain-pandangan dunia masyarakat yang memakai bahasa tersebut. Pandangan Izutsu tersebut tidak hanya sebatas alat berfikir dan berbicara, tetapi lebih pada penafsiran dan pengkonsepan dunia yang meliputinya. Dengan demikian konsep weltanschauung merupakan sebuah kajian sifat dan struktur pandangan dunia atas suatu bangsa dengan menggunakan mekanisme analisis metodologis terhadap konsep-konsep pokok yang telah diperoleh untuk dirinya sendiri dan telah mengkristal ke dalam kata-kata kunci bahasa itu sendiri ${ }^{5}$.

Izutsu menyatakan bahwa al-Qur'an dengan segala konsep di dalamnya dibiarkan untuk menjelaskan sendiri atau berbicara untuk dirinya sendiri tanpa terjadi eliminasi dalam memahami pandangan dunia atau weltanschauung al-Qur'an. Dalam hal ini, metode yang

\footnotetext{
${ }^{4}$ Aziz Anwar Fachrudin, Pengantar Sejarah Dan Mazhab Linguistik Arab (Sidoarjo: CV. Lisan Arabic, 2017). hlm.167.

${ }^{5}$ Toshihiko Izutsu, Relasi Tuhan Dan Manusia Pendekatan Semantik Terhadap Al-Qur'an, Terj, Agus Fahri Husein Dkk. (Yogyakarta: Tiara Wacana, 2003), hlm. 32.
} 
digunakan Izutsu adalah dengan cara menghimpun seluruh kata-kata penting yang merepresentsikan konsep-konsep penting seperti kata Allah, Islam, iman, kafir, Nabi, dan lain-lain yang kemudian makna kata-kata tersebut ditelaah dalam konteks al-Qur'an. Izutsu menyebut kata-kata penting tersebut dengan istilah kata kunci.

Konsep ini memberikan gambaran implisit bahwa tidak semua kata-kata dalam suatu kosakata mempunyai value yang sama dalam pengkonstruksian struktur dasar konsepsi ontologis yang didasarkan pada kosakata tersebut. Hal tersebut -menurut Izutsu- bukanlah pekerjaan yang mudah. Hal yang perlu menjadi perhatian adalah setiap kata di dalam alQur'an tidak sederhana dan simpel. Status dari setiap kata saling terpisah, namun mempunyai hubungan timbal balik atau korelasi yang sangat kuat antara satu dengan lainnya, dan makna konkret akan diperoleh dari seluruh sistem dengan adanya korelasi tersebut ${ }^{6}$.

\section{Klasifikasi dan Derivasi Ayat-ayat Zawj.}

Nabi Muhammad Salla Allah 'Alayhi wa Sallam mengemban risalah kenabian selama 23 tahun, 10 tahun diMakah dan 13 tahun di Madinah. Peristiwa ini tentu menimbulkan efek hukum tertentu dalam berbagai syari'at agama Islam, seperti terbentuknya istilah Makkiyah dan Madaniyyah dalam pengolongan surat dalam al-Qur'an. Kata zawj misalnya, satu term zawj saja sudah mempunyai perebedaan ketika ayat-ayatnya yang dikategorikan dalamMakkiyah dan Madaniyyah.

Adapun dalam al-Qur'an di sebutkan beberapa derivasi dari kata zawj. 21 Derivasi kata zawj sebanyak 81 kali diulangi dan tersebar dalam 43 surat. Sedangkan kata zawj terdapat dalam 72 ayat. Berikut perincian Makkiyah dan Madaniyyah katazawj beserta derivasinya dalam al-Qur'an.

\section{Makna Dasar Kata Zawj.}

Izutsu mendefinisikan makna dasar sebagai makna yang melekat dalam kata itu sendiri dan makna tersebut senantiasa hadir di mana pun kata itu diletakkan. Untuk bisa memperoleh makna dasar suatu kata atau derivasinya bisa dilakukan dengan mencarinya di dalam setiap kamus, dan di dunia linguistik dikenal dengan makna leksikal ${ }^{7}$.

\footnotetext{
${ }^{6}$ Izutsu. Relasi Tuhan Dan Manusia Pendekatan Semantik Terhadap Al-Qur'an, hlm. 33.

${ }^{7}$ Ibid., hlm. 12.
} 


\section{Analisis Semantik Kata Zawj dalam Al-Qur'an Marijatun Hujaz, Nur Huda, dan Syihabuddin Qalyubi Doi: doi.org/10.47454/itqan.v4i2.684}

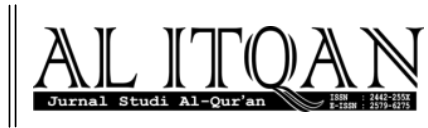

Kata zawj merupakan bentuk nomina verba yang berasal dari za' (j),wawu (و) dan jim (ج). Menurut Ibn Fāris, pada dasarnya kata zawj menunjukan pada makna perbandingan. Artinya, kata tersebut memiliki hubungan perbandingan dengan makna yang lain, yaitu pasangan ${ }^{8}$. Sementara menurut Ibn Manzūr dalam kitab Lisānul al- 'Arb menyatakan bahwa kata zawj merupakan antonim kata al-Fard (الفرد) sama halnya dengan Syaf'un (شفع) yang berarti genap dan Witrun (وتر) yang berarti ganji1

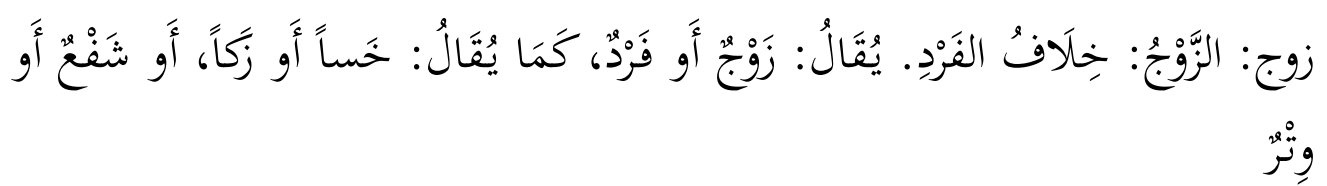

Ibn Sīdah mengatakan bahwa kata zawj bermakna seseorang yang mempunyai kawan atau bisa dikatakan dengan sesuatu yang dihubungkan denga yang lain. Kata zawj bisa bermakna dua (mutsanna) seperti kebiasaan orang Arab yang tidak pernah mengucapkan kata zawjdengan maksud tungggal, mereka tidak pernah mengatakan zawju hamimin(زوج حمام) yang bermakna sepasang burung merpati, namun mereka sering mengucapkan dengan uangkapan 'ind̄̄ zawjāni min al-ḥamīm (عندي زوجان من الحمام) maksudnya pejantan dan betina. Bentuk yang berpasangan ini disebabkan dua jenis yang berlawanan, seperti hitam putih, manis dan pahit. Ibn Sīdah mengatakan bahwa indikator yang menunjukkan penafsiran dari الزوجين bermakna dua ini adalah QS. An-Najm [53]: $45^{10}$.

\section{Makna Relasional Zawj.}

Makna relasional merupakan makna baru yang ditambahkan kepada makna dasar dengan cara meletakkan kata pada posisi khusus dalam bidang khusus pula. Makna relasional bisa juga dimaknai sebagai makna konotasi. Dengan demikian, makna baru tersebut menyesuaikan pada kalimat di mana kata tersebut diletakkan ${ }^{11}$. Analisa yang digunakan Izutsu dalam mencari makna relasional adalah menggunakan analisa sintagmatik dan paradigmatik.

\section{a. Analisa Sintagmatik}

\footnotetext{
${ }^{8}$ Ahmad bin Fāris, Mu'jam Maqāyīs Al-Lughah, ed. by Abdus Salam Muhammad Harun, vol. 3 (Beirut: Dār AlFikr, 1979), hlm. 35.

${ }^{9}$ Muhammad bin Mukrim bin Manzur, Lisān Al-Arab,vol. 2 (Beirut: Dar Shadir, tth), hlm. 291.

${ }^{10}$ Ibid,vol. 2, hlm. 291.

${ }^{11}$ Izutsu, Relasi Tuhan Dan Manusia Pendekatan Semantik Terhadap Al-Qur'an, hlm. 12.
} 
Analisa sintagmatik merupakan sebuah analisis yang digunakan untuk menemukan dan mengetahui suatu makna kata dengan cara melihat dan memerhatikan kata sebelum dan setelah kata yang menjadi pembahasan dalam suatu bagian tertentu ${ }^{12}$. Hal ini penting dan perlu untuk dilakukan karena makna sebuah kata pasti terpengaruh oleh kata-kata yang mengelilinya. Dalam konteks ini, makna kata zawj dapat diketahui melalui kata-kata yang mengelilinya. Terdapat enam makna relasional yang tersebar di dalam al-Qur'an antaralain; suami, istri, pasangan, hewan, tumbuhan, dan golongan.

\section{b. Zawj bermakna suami}

Kata Zawj memiliki arti suami ${ }^{13}$ seperti pada ayat,

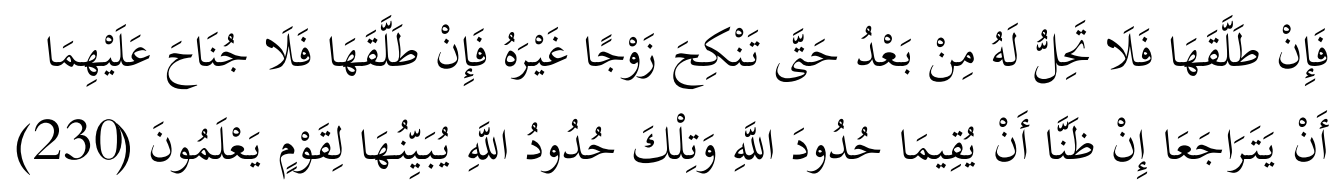

Kemudian jika dia menceraikannya (setelah talak yang kedua), maka perempuan itu tidak halal lagi baginya sebelum dia menikah dengan suami yang lain. Kemudian jika suami yang lain itu menceraikannya, maka tidak ada dosa bagi keduannya (bekas suami pertama dan istri) untuk kawin kembali jika keduanya berpendapat akan dapat menjalankan hukum-hukum Allah. Itulah hukum-hukum Allah, diterangkan-nya kepada kaum yang (mau) mengetahui (Q.S Al-Baqarah:230).

Ayat ini menjelaskan tentang konsep muhallil. Seorang istri yang ditalak tiga, jika suaminya ingin kembali lagi padanya, istri tersebut harus menikah dengan orang lain terlebih dahulu. Jika terjadi perceraian dengan suami kedua maka istri tersebut baru boleh menikah lagi dengan suami yang pertama. Di sini kata zawj bersanding dengan kata tankiha(menikah) yang merupakan bentuk verba serta memiliki keterkaitan dengan huruf $t a$ ' yang berada di awal sebagai penanda orang ketiga feminin. Sehingga ketika verba tersebut disandingkan dengan kata zawj yang berposisi sebagai objek, maka kata zawj memiliki makna suami dan komponan makna tersebut berupa manusia berjenis kelamin laki-laki.

\section{c. Zawj bermakna istri}

Kata Zawjbermakna istri ${ }^{14}$ seperti pada ayat,

\footnotetext{
${ }^{12}$ Izutsu, Relasi Tuhan Dan Manusia Pendekatan Semantik Terhadap Al-Qur'an, hlm. 32.

${ }^{13}$ Q.S Al-Baqarah [2]: 240, 232, Q.S dan QS. Al-Mujādalah [58]: 1;

${ }^{14}$ Q.S Al-Baqarah [2] : 25, 35, 240, 234 Q.S Al-Nisā' [4]: 1, 12, dan 57, Q.S Al-Tāubah [9]: 24, Q.S Al-Rũm [30]: 21, Q.S Al-Furqān [25]: 74, Q.S Tāhā [20]: 117, Q.S Al-Mu'minũn [23]: 6, Q.S Asy-Syu'arā [26]: 166, Q.S Al-Ra'du [13]: 38, Q.S al-Taghābun [64]: 14, Q.S Al-Tahrim [66]: 1 dan 5, Al-Zuhkruf [43]: 70, Q.S Yāsin [36]: 56, Q.S Ali-Imrān [3]: 15, Q.S Al-Anbiyā' [21]: 90. Q.S Al-Zumar [39]: 6, Q.S Al-Ahzāb [32]: 4 dan 37.
} 


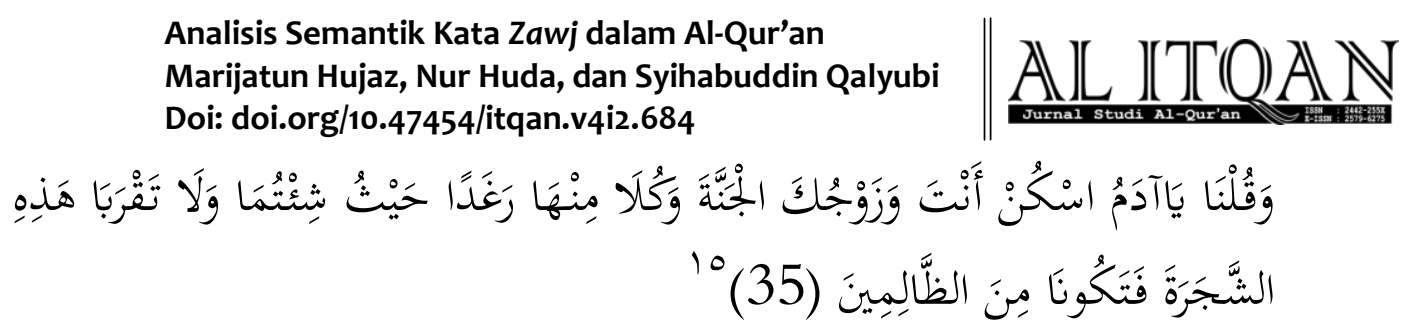

Dan kami Berfirman: "Hai Adam, diamilah oleh kamu dan istrinya surga ini, dan makanlah makanan-makananya yang banyak lagi baik dimana saja yang kamu sukai, dan janganlah kamu dekati pohon ini, yang menyebabkan kamu termasuk orang-oarang yang zalim.(Q.S Al-Baqarah:35).

Makna kata zawj bisa dipahami dari verba instruktif ( فعل الأمر)uskun dan pronomina tidak terikat (ضمير منفصل)antayang mendahului kata zawj sekaligus pronomina terikat ( ضمير (منصل) huruf kāf setelah kata zawj. Kata zawj pada ayat tersebut menunjukkan makna istri. Indikator yang digunakan adalah kata uskun yang berarti diamilah kamu yang diikuti dengan pronomina tidak terikat anta sebagai penegas orang ketiga maskulin. Artinya, Allah benarbenar memerintahkan nabi Adam dan istrinya untuk tinggal di surga bersama-sama.

\section{d. Zawj bermakna pasangan}

Zawj yang bermakna pasangan ${ }^{16}$ seperti pada ayat,

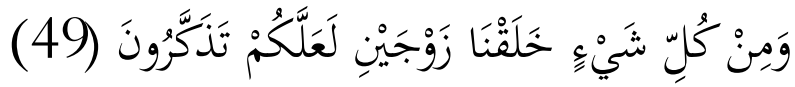

Dan segala sesuatu kami ciptakan berpasang-pasangan supaya kamu mengingat kebesaran Allah. (Q.S: Al-Żāriyat :49).

Pada ayat di atas, kata zawjmemiliki makna pasangan ketika disandingkan dengan kata kholaqnā yang berada sebelumnya. Maksud makna pasangan ialah segala sesuatu diciptakan berpasang-pasangan bukan hanya makhluk biologis seperti manusia, binatang, dan tumbuhtumbuhan mempunyai pasangan, laki-laki dan perempuan, jantan dan betina, tetapi juga makhluk-makhluk lain seperti makhluk kosmologis. Selain itu, al-Qur'an juga sering kali menyebutkan fenomena kosmologis seperti halnya langit dan bumi, siang dan malam, musim dingin dan musim panas, dunia dan akhirat. ${ }^{17}$

\section{e. Zawj Bermakna Jenis Hewan}

Kata Zawj bermakna hewan ${ }^{18}$ seperti pada ayat,

\footnotetext{
${ }^{15}$ Q.S Al-Baqarah [2] : 35

${ }^{16}$ QS. Al-Żāriyat [51]: 49 Q.S Yāsin [36]: 36, Q.S Al-Nabā' [78]: 8, Q.S Al-Nājm [53]: 45, Q.S al-Qiyāmah [75]: 39, Q.S Asy-Syurā' [42]: 11.

${ }^{17}$ Manzur, Lisān Al-Arab,vol. 2, hlm. 293.

${ }^{18}$ Q.S Al-An'ām [6]: 143, Q.S Hũd [11]: 40.
} 


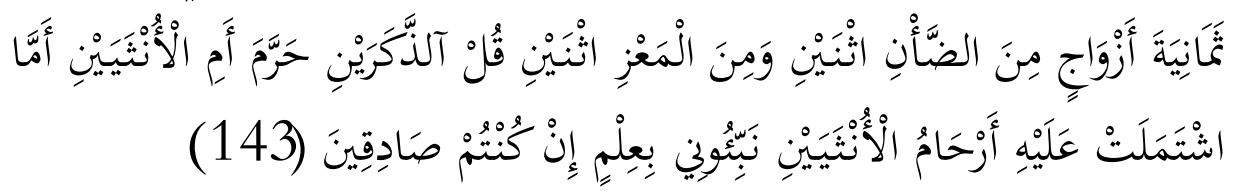

(Yaitu) Delapan binatang yang berpasangan, sepasang domba, sepasang dari kambing. Katakanlah: "Apakah dua yang Jantan yang diharamkan Allah ataukah dua yang betina, ataukah yang ada dalam kandungan dua betinanya?" Terangkanlah kepada dengan berdasar pengetahuan jika kamu memang orangorang yang benar. (Q.S Al-An'ām: 143).

Pada ayat di atas, kata zawj ditampilkan dalam bentuk plural (azwāj) bersandingan dengan frasa numeria al-ḍa'ni iśnaini. Kata al-ma'zi yang berada setelah kata azwāj dan kata iśnaini dalam ayat di atas menunjukkan kepada jenis jantan dan betina pada jenis binatang. Jadi kata iśnaini penegasan kepada hal-hal yang bersifat biologis yang lebih menunjukkan kepada pasangan hewan atau binatang yaitu jantan dan betina.

\section{f. ZawjBermakna Tumbuhan}

Zawj yang bermakna tumbuhan ${ }^{19}$ seperti pada ayat,

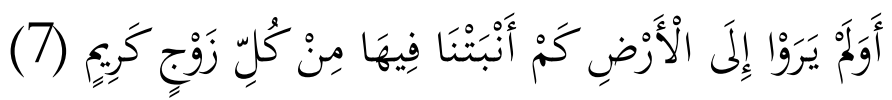

Dan apakah mereka tidak memperhatikan bumi, berapakah banyaknya kami tumbuhkan di bumi itu perbagai macam tumbuhan-tumbuhan yang baik? (Q.S Asy- Syuara': 7)

Pada ayat di atas, kata zawjbersanding dengan kata ambatnā yang telah mendahuluinya menunjukkan makna tumbuhan, yang secara leksikologis bermakna menumbuhkan. Maksud tumbuhan pada ayat tersebut, ialah tumbuhan yang diciptakan Allah dengan cara berpasang-pasangan. Sebagian tumbuhan ada yang memiliki benang sari dari putik sehingga menyatu dalam diri pasanganya dan dalam penyerbukannya ia tidak membutuhkan pejantan dari bunga lain, dan ada juga yang hanya memiliki salah satunya saja sehingga membutuhkan pasangannya ${ }^{20}$.

\footnotetext{
${ }^{19}$ Q.S Asy-Syu'arā' [26]: 7, Q.S Tāhā [20]: 53, Q.S Ar-Rahman [55]: 52, Q.S Al-Hājj [22]: 5, Q.S Luqmān [31]: 10,

${ }^{20}$ M. Quraish Shihab, Tafsir Al-Misbah: Pesan, Kesan Dan Keserasian Al-Qur'an, vol. 12 (Jakarta: Lentera Hati, 2002), hlm. 100.
} 


\section{g. ZawjBermakna Golongan}

Zawj yang bermakna golongan ${ }^{21}$ seperti pada ayat,

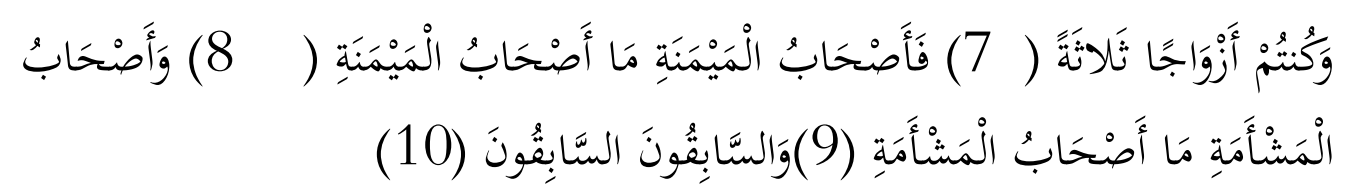

dan kamu menjadi tiga golongan (7), yaitu golongan kanan, alangkah mulianya golongan kanan itu (8). dan golongan kiri, alangkah sengsaranya golongan kiri itu (9). dan orang-orang yang beriman paling dahulu (10). (QS. Al-Wāqi'ah : 7-10).

Pada ayat ini, kata zawj dimunculkan dalam bentuk plural, azwāj. Kata zawj dimaknai dengan golongan karena bersanding dengan kata śalāśah. Selain itu, indikasi yang menguatkan bahwa kata zawj bermakna golongan adalah tiga kata berikutnya yang berbentuk frasa apositif (tarkīb badali), sebagai penjelasan dan penjabaran kata śalāśah. Ketiganya adalah aṣhāb al-maimanah (golongan kanan), aṣhāb al-masy'amah (golongan kiri), dan alsābiqūn (golongan terdahulu yang beriman).

\section{Analisa Paradigmatik}

Analalisa jenis ini merupakan bentuk komparasi konsep tertentu dengan konsep yang mirip (sinonim) atau yang bertentangan (antonim) $)^{22}$.

\section{Sinonimitas kata zawj dalam al-Qur'an}

Sesungguhnya kata zawj memiliki kemiripan atau kesamaan (sinonim) dengan kata lain di dalam al-Qur'an. Terdapat lima kata yang semakna atau berdekatan makna dengan kata zawj, yaitu al-ba'l, al-rijāl, al-mar'ah, al-nisā', dan qarīn.

\section{a. Al-Ba'l}

Kata $b a^{\prime} l$ bermakna nikah dan bermain-main (menggauli istri), sebagaimna sabda Rasullullah mengenai hari tasyrīq: "hari-hari tasysrīq merupakan hari diperbolehkannya makan, minum, dan bersetubuh". Kata $a l-b a^{\prime} l$ juga bisa diartikan sebagai suami, dewa, tuhan dan tanah dataran tinggi yang tidak terkena hujan kecuali sekali dalam setahun ${ }^{23}$. Sementara dalam konteks al-Qur'an, kata $b a^{\prime} l$ muncul dengan makna yang berbeda, yaitu suami dan patung. Kata $b a^{\prime} l$ disebutkan dalam al-Qur'an sebanyak 5 kali. Di dalam al-Qur'an

\footnotetext{
${ }^{21}$ QS.Al-Wāqi’ah [56]:7-10, QS. Al-Hijr [15]: 88, dan QS. Tāhā [20]: 131.

${ }^{22}$ Izutsu, Relasi Tuhan Dan Manusia Pendekatan Semantik Terhadap Al-Qur'an, hlm. 32.

${ }^{23}$ Manzur, Lisan Al- 'Arab, vol. 11, hlm. 57.
} 
juga ditemukan bahwa kata $b a^{\prime} l$ memilliki kesamaan dengan makna zawj yaitu suami, seperti yang dijelaskan dalam surat al-Nisā' [4]: 128;

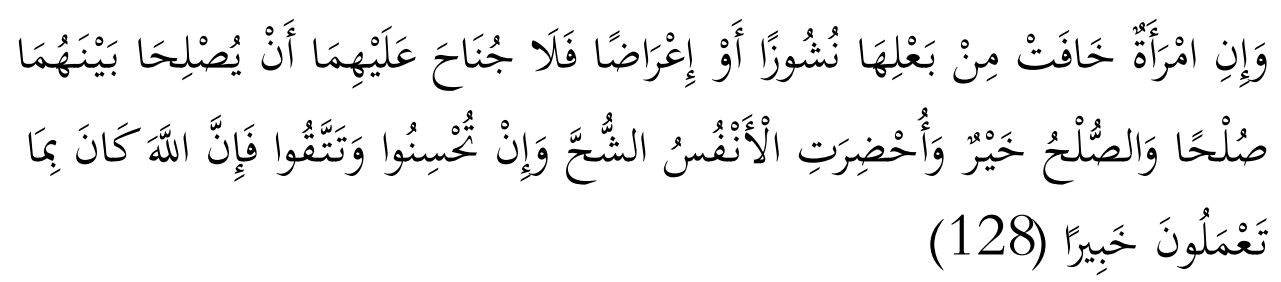

Dan jika seorang perempuan sepasang khawatir suaminya akan nuyuz atau bersikap tidak acuh maka keduanya dapat mengadakan perdamaian yang sebernarnya, dan perdamaian itu lebih baik (bagi mereka) walaupun manusia itu menurut tabiatnya kikir dan jika kamu memperbaiki (pergaulan dengan istrimu) dan memelihara dirimu (dari nusyuz, sikap tidak acuh dan bertindak tidak adil),maka sesungguhnya Allah Maha teliti terhadap apa yang kamu kerjakan. (QS. Al-Nisā' : 128).

Pada ayat di atas, kata $b a^{\prime} l$ tampil dalam bentuk tunggal. Kata $b a^{\prime} l$ dalam ayat tersebut bermakna suami, dilihat dari konteks ayat dan struktur kalimat pada ayat tersebut. Sebelum kata $b a^{\prime} l$ terdapat kata imra'atun yang artinya istri. Dalam ayat tersebut kemudian muncul sebuah verba, yaitu khäfat yang merupakan verba perfektif dengan diakhiri oleh $t a$ ' sebagai pengganti orang ketiga feminin. Orang ketiga yang dimaksud adalah imra'atun, seorang istri yang merupakan istri dari $b a^{\prime} l$, seorang suami. Dapat disimpulkan bahwa kata $b a^{\prime} l$ mengandung makna suami dan memiliki komponen makna berupa manusia berjenis kelamin laki-laki ${ }^{24}$.

\section{b. Al-Rijāl}

Kata al-rijāl merupakan bentuk plural dari kata al-rajul yang berasal dari akar kata ra'-jim-lam (נ (נ) - J) yang mempunyai banyak makna, antara lain: ra-ja-la (mengikat), ra-jila (berjalan kaki), ar-rijl (telapak kaki), ar-rijlah (tumbuh-tumbuhan), dan al-rajul (lakilaki) ${ }^{25}$. Adapun kata al-rajul (الرجل dibaca fatah pada huruf $\mathrm{J}$ dan dibaca damah pada huruf artinya seorang laki-laki yang baligh dari keturunan Nabi Adam. Kata tersebut berkebalikan dengan kata al-mar'atu (المرأة) dan secara umur lebih tua dari pada kata al-gulàm. Adapun kalimat al-rājilu khilāf al-fārisi ( الراجل خلاف الفارس) mempunyai makna pejalan kaki, bukan penunggang kuda, sebagaimana yang ditegaskan dalam al-Qur'an ${ }^{26}$.

\footnotetext{
${ }^{24}$ Ibrahim Musthafa Dkk., Al-Mu'jam Al-Wasit, edisi 1 (Istambul: Al-Maktabah Al-Islamiyyah, 1999), hlm. 64.

${ }^{25}$ Nasaruddin Umar, Argumen Kesetaraan Gender Dalam Al-Qur'an, 11th edn (Jakarta: Paramadina, 2001). hlm. 144.

${ }^{26}$ Manzur, Lisan Al- 'Arab, XI. hlm. 265.
} 


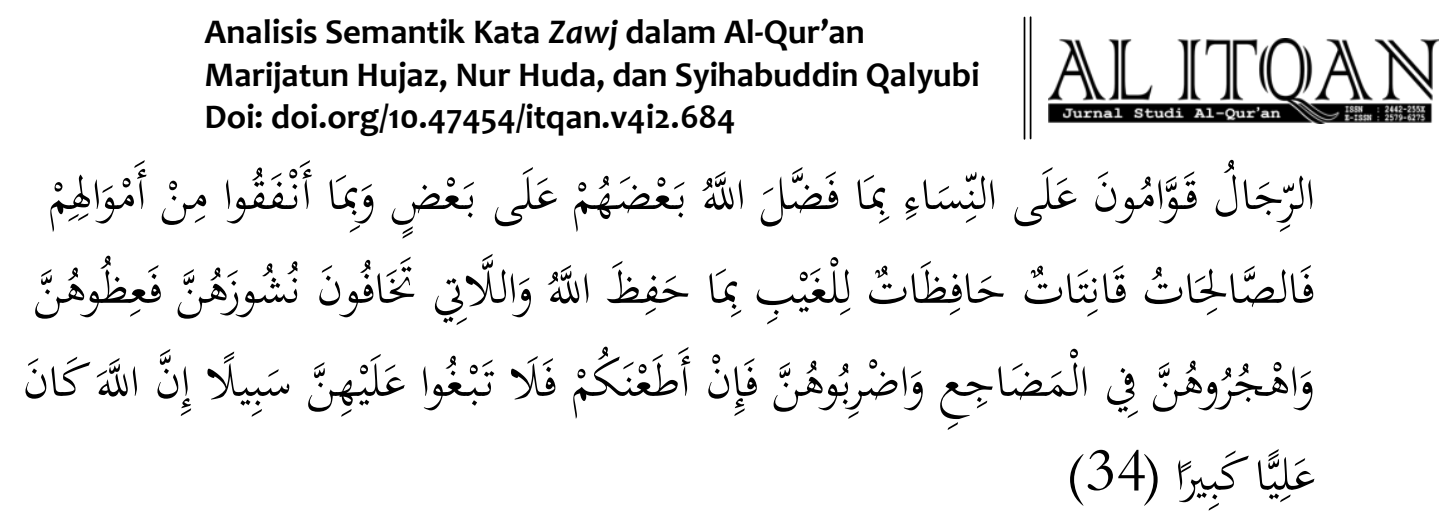

Kaum laki-laki itu adalah pemimpin bagi kaum wanita, oleh karena Allah melebihkan sebagain mereka (laki-laki) atas sebagian yang lain (wanita ), dan karena mereka (laki-laki) telah menafkahkan sebagain dari harta mereka. Sebab itu maka wanita yang saleh, ialah yang taat kepada Allah lagi memelihara diri ketika suaminya tidak adan, oleh karena Allah telah memlihara (mereka). Wanita-wanita yang kamu khawatirkan nusyuznya, maka nasehatilah mereka dan pisahkan mereka mereka di tempat tidur meraka, dan pukullah mereka. Kemudian jika mereka mentaatimu. Meka jangan kamu mencari-cari jlan untuk menyusahkannya. Sesungguhnya Allah Maha Tinggi lagi Maha besar.( al-Nisā 4:34).

Pada ayat di atas, kata al-rijāl sebagai bentuk plural dari kata al-rajul diartikan sebagai suami, karena setelah kata al-rijāl terdapat kata anfaqū yang merupakan bentuk orang ketiga yang memiliki kewajiban menafkahi istri. Singkatnya, kata al-rijāl dalam ayat tersebut mengandung makna suami dan memiliki makna laki-laki berusia balig dalam anggota keluarga $^{27}$.

\section{c. Imra'atun}

Kata imra'atun merupakan bentuk lain dari kata mar'atun. Keduanya berasal dari kata maru'a (مرؤ) atau mara'a dan mari'a (مرأو مرئ) yang memiliki arti enak jika disandingkan dengan kata al-ṭa'ām (الطعام). Jika disandingkan dengan kata al-rajulu (الرجل) maka kata tersebut bermakna laki-laki yang pemberani dan berwibawa. Sementara bentuk nomina verba kata tersebut adalah murū'atan (مروءء) yang bermakna kewibawaan, keberanian, dan kehormatan. Orang Arab jika ingin membuat nomina definit (ma'rifah) kata mar'atun, maka mereka mendatangkan alif dan lam sehingga berbunyi al-imra'atu. Perubahan ini kembali kepada bentuk lain dari kata mar'atun, yakni imra'atun yang telah didatangkan alif waşal sebagaimana dikatkan juga oleh Ibnu al-Anbarī. Kata imra'atun juga menunjukkan makna kesempurnaan perempuan atau perempuan dewasa sebagaimana antonim kata tersebut, yakni al-rajulu yang bermakna laki-laki dewasa ${ }^{28}$. Ibnu Fāris menyatakan bahwa kata al-mar'ah

\footnotetext{
${ }^{27}$ Zaitunah Subhan, Al-Qur'an Dan Perempuan: Menuju Kesetaraan Gender Dalam Penafsiran (Jakarta: Kencana Prenada Media Group, 2015). hlm. 17.

${ }^{28}$ Muhammad bin Mukrim bin Manzur, Lisan Al-' Arab, vol. 1, (Beirut: Dar Shadir), hlm. 154.
} 
memiliki hubungan pasangan dengan kata $a l-b a ' l$ atau $a l$-zawj. Dengan kata lain, al-mar'ah berarti istri dari $a l-b a^{\prime} l^{29}$.

Di dalam al-Qur'an, kata imra'atun yang merujuk kepada makna istri setidaknya ditemukan sejumlah tujuh belas ayat dalam tiga belas surah, yaitu QS. Āli 'Imrān [3]: 35, QS. An-Nisā' [4]: 128, QS. Al-A'rāf [7]: 83, QS. Hūd [11]: 71 dan 81, QS. Yūsuf [12]: 21, 30, dan 51, QS. Al-Hijr [15]: 60, QS. Maryam [19]: 5 dan 8, QS. An-Naml [27]: 57, QS. AlQașaṣ [28]: 9, QS. Al-Ankabūt [29]: 32, QS. Al-Żāriyaāt [51]: 29, QS. Al-Tahrīm [66]: 10 dan 11, dan QS. Al-Lahab [111]: 4. Dari ketiga belas surah tersebut teridentifikasi bahwa makna istri terbagi menjadi dua kategori.

Pertama, kategori istri yang terhormat dan menjaga kehormatan suami, yaitu QS. Âli 'Imrān [3]: 35, QS. QS. An-Nisā' [4]: 128, QS. Hūd [11]: 71, QS. Yūsuf [12]: 21, 30, dan 51, QS. Maryam [19]: 5 dan 8, QS. Al-Qașaṣ [28]: 9, QS. Al-Żāriyaāt [51]: 29, dan QS. AlTahrīm [66]: 11.

Kedua, kategori istri yang sebenarnya terhormat karena suaminya memiliki kedudukan terhormat (hamba saleh atau nabi), namun istri tersebut tidak bisa menjaga kehormatan suaminya, yaitu QS. Al-A'rāf [7]: 83, QS. Hūd [11]: 81, QS. Al-Hijr [15]: 60, QS. An-Naml [27]: 57, QS. Al-Ankabūt [29]: 32, QS. Al-Tahrīm [66]: 10, dan QS. Al-Lahab [111]: 4.

Dengan demikian, makna kata imra'ah di sini adalah seorang perempuan dewasa yang sudah bersuami dan memiliki kedudukan terhormat dalam masyarakat atau di hadapan Allah SWT.

\section{d. Al-Nis̄̄}

Kata al-nis $\bar{a}$ ' diambil dari akar kata nasā (نسا) yang meninggalkan sesuatu, atau menempati kedudukan nasiya (نسي) yang bermakna meninggalkan sesuatu karena lupa atau lalai. Kata al-nisā merupakan bentuk plural dari kata imra'atun, namun bukan dari darivasi kata tersebut ${ }^{30}$. Kata al-nis̄̄' berarti gender perempuan, sepadan dengan kata al-Rijāl yang berarti laki-laki. Selain gender perempuan, kata tersebut juga berarti istri seperti kata alzawj $j^{31}$.

\footnotetext{
${ }^{29}$ Faris, Mu’jam Maqāȳis Al-Lughah, III. hlm. 26.

${ }^{30}$ Muhammad bin Mukrim bin Manzur, Lisan Al-'Arab (Beirut: Dar Shadir, Tt), XV. hlm. 321

${ }^{31}$ Umar, Argumen Kesetaraan Gender Dalam Al-Qur'an. hlm. 160.
} 


\section{Analisis Semantik Kata Zawj dalam Al-Qur'an Marijatun Hujaz, Nur Huda, dan Syihabuddin Qalyubi Doi: doi.org/10.47454/itqan.v4i2.684}

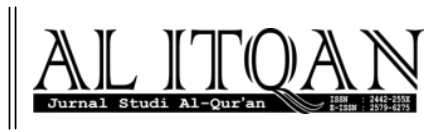

Kata al-nis $\bar{a}$ ' yang memiliki arti istri paling tidak ditemukan sejumlah 18 ayat dalam 6 surah, yaitu QS. Al-Baqarah [2]: 187, 222, 223, 226, 231, 232, dan 236, QS. Āli Imrān [3]: 61, QS. Al-Nisā' [4]: 22, 23, 24, dan 34, QS. Al-Aḥzāb [33]: 30, 32, dan 59, QS. AlMujādalah [58]: 2, QS. Al-Ṭalaq [65]: 1 dan 4. Seluruhnya menunjukkan makna istri dari perspektif jenis kelamin, bukan secara fungsional atau peran.

\section{e. Qarīn}

Kata qarīn (قرين) merupakan derivasi kata qarana (قرن) (قترن) (قرن) yatau iqtarang memiliki arti șăḥaba (صاحب) yakni menyertai atau menemani. Kata qarīn sendiri memiliki arti teman, sahabat, kawan. Namun demikian, qaīn di sini terbagi menjadi dua. Pertama, dia direpresentasikan pada malaikat yang senantiasan mengajak kepada kebaikan. Kedua, direpresentasikan pada setan yang mengajak kepada kejelekan dan keburukan ${ }^{32}$. Di tempat lain Ibnu Manzūr menyatakan bahwa qarīn bisa diartikan sebagai mitra atau individu yang memiliki pasangan ${ }^{33}$.

Di dalam al-Qur'an, kata qaīn ditemukan sejumlah enam ayat pada empat surah yang berbeda, yaitu QS. Al-Nisā' [4]: 38, QS. Al-Șaffāt [37]: 51, QS. Al-Zuhrūf [43]: 36 dan 38, QS. Qāf [50]: 23 dan 27. Semua ayat tersebut menunjukkan bahwa kata qarīn bermakna teman yang mengajak kepada keburukan yang direpresentasikan kepada setan, kecuali satu pada QS. Qāf [50]: 23. Pada ayat tersebut, qarīn yang dimaksud adalah malaikat yang mengajak kepada kebaikan.

\section{Antonimitas Kata Zawjdalam Al-Qur'an}

Menurut hemat penulis, antonimitas kata zawj hanya ditemukan dua kata, yairu kata al-fardu dan al-witru.

\section{a. Fardun}

Kata fardun merupakan derivasi verba nomina yang berasal dari verba farada (فرد). Kata fardun bermakna terpisah dari sesuatu yang membersamainya (sendiri), seperti padaredaksi (فلان فرد في داره fulānun fardun fì dārihi yang bermakna fulan sendiri di rumah (tidak ada temannya). Di antara makna al-fard adalah satu, sendirian, tunggal, individu, dan

\footnotetext{
${ }^{32}$ Muhammad bin Mukrim bin Manzur, Lisan Al-'Arab (Beirut: Dar Shadir, Tt), XIII. hlm. 331.

${ }^{33}$ Manzur, Lisan Al-' Arab, II, hlm. 291.
} 
perseorangan ${ }^{34}$. Dalam lisān al- 'Arb, secara leksikal kata tersebut bisa diartikan dengan alwitru (ganjil) dan memiliki bentuk plural afrādun dan furādā yang tidak mengikuti hukum qiyas. Imam Al-Laiś berpendapat bahwa al-wahid dan al-ahad artinya sama halnya dengan fardun, yaitu satu atau tunggal ${ }^{35}$.

Dalam al-Qur'an, kata fardun hanya ditemukan sejumlah tiga ayat dalam dua surat yang berbeda, yaitu QS. Maryam [19]: 80 dan 95, dan QS. Al-Anbiyā' [21]: 89.

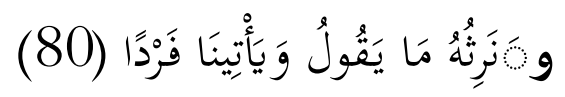

Dan Kami akan mewarisi apa yang ia katakan itu[909], dan ia akan datang kepada Kami dengan seorang diri”. (QS. Maryam : 80)

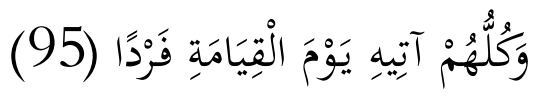

Dan tiap-tiap mereka akan datang kepada Allah pada hari kiamat dengan sendiri-sendiri”. (QS. Maryam : 95)

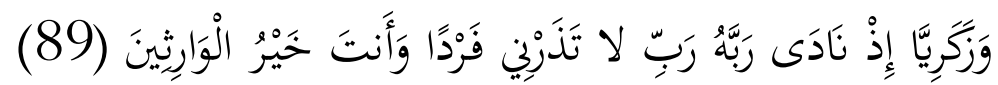

Dan (ingatlah kisah) Zakaria, tatkala ia menyeru Tuhannya: "Ya Tuhanku janganlah Engkau membiarkan aku hidup seorang diri dan Engkaulah waris yang paling Baik.(QS. Al-Anbiyā' : 89)

Pada QS. Maryam: 80, Ibn Kathīr menyatakan bahwa maksud dari fardan adalah orang-orang kafir akan datang kepada Allah seorang diri, tanpa membawa anak dan harta yang mereka katakan sebelumnya ${ }^{36}$. Sementara pada ayat 95 dalam surah yang sama, maksud sendiri adalah bahwa di hari kiamat mereka datang seorang diri tanpa sang penolong dan pendukung ${ }^{37}$. Adapun makna fardan dalam konteks ayat 89 surah Al-Anbiyā', nabi Zakariya berdoa kepada Allah supaya dia tidak hidup seorang diri dan berharap kepada Allah supaya diberikan keturunan yang bisa mewarisi dan melanjutkan dakwahnya ${ }^{38}$.

\section{b. Al-witru atau al-watru}

Kata al-witru atau al-watru (الوتر) adalah dua kata yang memiliki makna sama dengan al-fardu (الفرد), yakni tuggal atau ganjil. Kata tersebut berkebalikan dengan kata al-syaf'u

\footnotetext{
${ }^{34}$ Abu Hilal Al-Askari, Mu'jam Al-Furuq Al-Lugawiyah (Damaskus: Mu'assasah al-Nasyr al-Islamiy, 2000). hlm. 140.

${ }^{35}$ Muhammad bin Mukrim bin Manzur, Lisan Al-'Arab (Beirut: Dar Shadir), III. hlm. 331.

${ }^{36}$ Muhammad bin Umar bin Kaśīr, Tafsìr Al-Qur'ān Al-'Azīm, 2nd edn (Beirut: Dār Al-Tayyibah, 1999), v. hlm. 261.

${ }^{37}$ Muhammad bin Jarīr Al-Tabari, Jam̄̄' Al-Bayān F̄̄ Ta'wīl Al-Qur'ān, ed. by Ahmad Muhammad Syakir (Beirut: Mu'assasah al-Risālah, 2000), XVIII. hlm. 261.

${ }^{38}$ Ibnu Kasir, Tafsìr Al-Qur'än Al-'Ażìm, v. hlm. 370.
} 


\section{Analisis Semantik Kata Zawj dalam Al-Qur'an Marijatun Hujaz, Nur Huda, dan Syihabuddin Qalyubi Doi: doi.org/10.47454/itqan.v4i2.684}

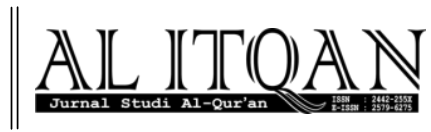

(الثفع) yang bermakna genap. Sehingga ada sebagian kelompok mengatakan bahwa makna alwitru adalah Allah Yang Maha Esa (اله الواحد), sementara kata al-syaf'u diperuntukkan untuk semua makhluk-Nya yang diciptakan berpasang-pasang ${ }^{39}$.

Dalam al-Qur'an, kata al-watru hanya ditemukan dalam QS. Al-Fajr [89]: 3. Ibnu Abbas dan Mujahid menyatakan bahwa kata al-watru menunjuk pada makna bahwa Allah itu Tunggal (Esa), sementara makhluk-Nya tercipta genap atau berpasang-pasang. Ada pula yang mengatakan bahwa al-watru menunjuk jumlah shalat Magrib, sementara kata al-syaf'u menunjuk jumlah shalat subuh ${ }^{40}$.

\section{E. Makna Sinkronik dan Diakronik kata Zawj}

Analisis sinkronik dan diakronik sangat diperlukan untuk memperoleh makna yang mendalam dalam suatu kajian semantik. Sinkronik merupakan aspek kata yang statis, artinya konsep yang menjadi obyek kajian senantiasa tetap dan tidak berubah. Sementara diakronik merupakan aspek kumpulan kata yang masing-masing berubah secara dinamis dan tumbuh subur dengan caranya sendiri. Izutsu mencoba menawarkan kategori ini dengan membagi tiga periode waktu penggunaan kosa kata, yakni pra-Qur'anik, Qur'anik, dan pasca-Qur'anik ${ }^{41}$.

\section{Periode Pra-Qur'anik}

Untuk menelisik pandangan suatu kata pada era Arab kuno, sistem periode praQur'anik adalah saranan yang tepat dengan menelusuri kosa kata badui atau orang pedalaman. Ada pula kosa kata yang diperoleh dari para pedagang; kafilah dagang dan kosa kata yang merupakan bagian dari sistem tema-tema religius Yahudi-Kristen yang pernah hidup di tanah Arab. Bangsa Arab kuno menyatakan bahwa syair merupakan bagian dari produk budaya terbesar yang biasa digunakan untuk mendeskripsikan kisah roman, pengecaman terhadap musuh, peperangan, dan solodaritas kelompok ${ }^{42}$.

\footnotetext{
${ }^{39}$ Muhammad bin Mukrim bin Manzur, Lisan Al-'Arab (Beirut: Darus Shadir, Tt), v. hlm. 273.

${ }^{40}$ Muhammad bin Umar bin Kaśīr, Tafsīr Al-Qur'ān Al-'Az̄ìm, 2nd edn (Beirut: Dār Al-Tayyibah, 1999), VIII. hlm. 392.

${ }^{41}$ Izutsu, Relasi Tuhan Dan Manusia Pendekatan Semantik Terhadap Al-Qur'an, hlm. 35.

${ }^{42}$ Ingrid Matson, Ulumul Qur'an Zaman Kita (Jakarta: Zaman, 2013). hlm. 28.
} 
Pencarian makna zawj pada masa ini melalui penelusuran karya-karya kuno Jahiliyyah. salah satu penyair Jahiliyyah yang masyhur adalah Labīd bin Rabīah ${ }^{43}$. Dalam syair Labīd Ibn Rabīah kata zawj hanya terekspos satu kali, yakni:

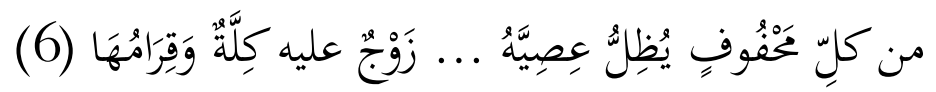

dari setiap tutup yang mengelilingi berupa permadani itu menaungi pemotongan kayu dan kanan kirinya sekedup.

Adapun penjelasan potongan syair itu adalah sebagai berikut :

$$
\begin{aligned}
& \text { حفَّ الهودج وغيره بالثياب: إذا غطي بها، وحف الناس حول الشيء أحاطوا به. } \\
& \text { أظلّ الجدار الشيء: إذاكان في ظل الجدار. العصي هنا: عيدان الهودج. الزوج: } \\
& \text { النمطمن الثياب، والجمع الأزواج. الكِلّة: الستر الرقيق، والجمع الكلل. القرام: الستر، } \\
& \text { والجمع القرم، ثم فصل الظعن فقال: هي من كل هودج حُفَّ بالثياب يظل عيدانه } \\
& \text { نمط أرسل عليه، ثم فصل الزوج فقال: هو كِلة، وعبر بها عن الستر الذي يلقى فوق } \\
& \text { الهودج لئلا تؤذي الشمس صاحبته، وعبر بالقرام عن الستر المرسل على جونب } \\
& \text { الهودج، وترير المعنى: الهوادج ححفوفة بالثياب فعيداها تحت ظلال ثياها، والمضمر بعد } \\
& \text { القرام للعصى أو الكِلّة. }
\end{aligned}
$$

Maksud dari kata al- 'ișiyyu di sini adalah potongan kayunya sekedup.al-Zawjpada syair ini senada denganal-namāțu, yakni permadai yang tersusun melingkari sekedup yang terbuat dari pakaian, dan bentuk pluralnya adalahal-azwāju. Al-killatu adalah tutup yang tipis, dan bentuk pluralnya adalah al-kilalu. Al-qirāmuadalah tutup atau satir, bentuk pluralnya adalah qaramu. Kemudian dijelaskan tentang sekedup, yaitu setiap sekedup dikelilingi dengan pakaian yang menutupi potongan kayu permadani. Maksud al-zawj adalah tutup yang tipis dan diibaratkan dengan killah yaitu tutup yang berada di atas sekedup untuk mencegah terik

\footnotetext{
${ }^{43}$ Memiliki nama asli Abu Aqil Labīd Ibn Rabīah Amiri. Dia dilahirkan dari keluarga yang mulia dan dermawan, termasuk penyair jahiliyah berusia panjang (145 tahun) dan memeluk agama Islam pada tahun 626 Masehi, kemudian pindah ke kota Kūfah dan tinggal di sana mengisi akhir hidupnya sampai meninggal tahun $661 \mathrm{M}$. Dia sempat tergolong masuk periode atau masa Islam. Namun demikian, penyair ini tetap digolongkan sebagai penyair jahiliyyah karena sesudah masuk Islam, penyair ini tidak lagi mendendnagkan puisi kecuali hanya satu bait saja. Bakat penyair ini telah dapat dilihat sejak masa kecilnya. Dalam suatu riwayat dikatakana bahwa Labīd, di masa kecilnya bertemu dengan salah satu penyair jahiliyyah yaitu Nābighah di majelisnya. Di majelis itu, Nābighah sangat memperhatikannya. Ketika ditanya nama sukunya kemudian Nābighah berkata padanya:"hai anak kecil nampaknya kamu berbakat dalam puisi, apakah kamu dapat mengucapkan puisi?". dengan spontan Labīd berpuisi dengan baik sehingga Nabighah takjub dan berkata, "pergilah hai anak, sesungguhnya kamu akan menjadi penyair suku Qiās yang paling terkenal". Lihat Bachrum Bunyamin and Hamday Salad, Syair-Syair Arab Pra Islam: Al-Muallaqat (Yogyakarta: Gading Pustaka, 2017). hlm. 30.
} 


\section{Analisis Semantik Kata Zawj dalam Al-Qur'an Marijatun Hujaz, Nur Huda, dan Syihabuddin Qalyubi \\ Doi: doi.org/10.47454/itqan.v4i2.684}

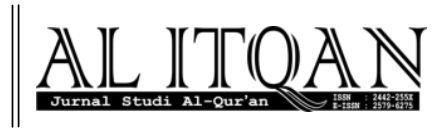

matahari.Qirām diibaratkan dengan sesuatu tutup yang berada di kanan dan kiri sekedup. Atau benda barang yang diletakkan di atas punggung unta sebagai tempat untuk wanita yang diselimuti oleh pakaian atau kain yang tipis, fungsinya adalah untuk mencegah dari sinar matahari, dan tiang sekedup terletak dibawah penutup kain ${ }^{44}$.

Dapat diambil kesimpulan bahwa yang dimaksud dengan kata zawj pada syair jaihiliyah pra-Quranik diartikan sebagai tipe permadani yaitu sebuah kain tipis yang digunakan sebagai penutup atau selimut bagi kaum laki-laki atau perempuan (pasangan). Selain itu, kata al-namțu menunjukkan varian atau style yang tentu lebih dari satu.

\section{Periode Qur'anik}

Periode Qur'anik merupakan sistem yang muncul pada kurun waktu al-Qur'an diturunkan. Dalam hal ini, Nabi Muhammad memegang otoritas yang dominan dalam pembentukan konsepsi al-Qur'an. Sedangkan batasan periode Qur'anik adalah pada zaman alQur'an diturunkan, yakni selama 23 tahun. Pemaknaan kata zawj akan lebih maksimal ketika mengetahui konteks sosio historis pada masa itu. Dalam hal ini, ayat-ayat al-Qur'an yang menyebutkan tentang kata zawj lebih banyak diturunkan di Mekkah dari pada di Madinah. 27 ayat diantaranya terdapat di al-Qur'an periode Makkiyah dan 16 lainnya tedapat dalam alQur'an periode Madaniyyah.

Pada periode Makkah, makna zawj tidak mengalami perubahan makna, tetap dengan makna pada al-Qur'an yang fokus pada penekanan terhadap isi redaksi yang menunjukan penggambaran-penggambaran terhadap tanda kebesaran Allah dan kenikmatan-kenikmatan yang akan didapatkan seseorang yang bersedia mengikuti jalan Islam. Kerena misi yang diemban Rasulullah pada masa itu adalah misi Tauhid, yaitu meyakinkan penduduk Mekkah yang kala itu memegang paham politheisme menjadi monotheisme hanya dengan menyembah Allah sebagai satu-satunya Tuhan. Sebagai contoh, QS. Șaffăt [37]: 22;

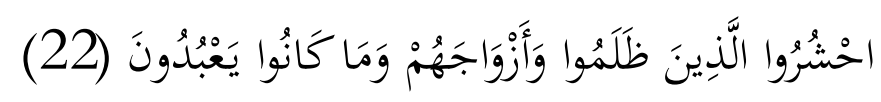

(kepada malaikat diperintahkan)" kumpulkanlah orang-orang yang zalim beserta teman sejawat (azwāj) mereka dan sembahan-sembahan yang selalu mereka sembah. (QS. Șaffāt : 22).

\footnotetext{
${ }^{44}$ Labib bin Rabiah Al-Amiri, Diwan Labib Bin Rabiah Al-Amiri, Edisi I, (Mesir: Dar al-Ma'rifah, 2004), hlm. 99.
} 
Ayat ini menjelaskan tentang orang-orang zalim yang menyembah selain Allah. Orang-orang yang mengikuti jalan setan dengan mempelajari sihir. Dalam tafsir Quraish Shihab dikatakan bahwa kata $a z w a \bar{j}$ diartikan sebagai pasangan yang hidup di dunia yakni, suami istri yang sama-sama musyrik atau durhaka atau bisa diartikan dengan teman sejawat yang sama dalam kedurhakaanya. ${ }^{45}$ Pendapat lain mengatakan, dimaksud adalah setan yang selalu menemani manusia, maka kata tersebut dinamai oleh al-Qur'an dengan sebuatan qārin.

Dari penjelasan di atas dapat diberi kesimpulan bahwa orang-orang yang menyekutukan Allah atau menyembah selain Allah maka dia akan dimasukan kedalam neraka jahanam seperti yang dijelaskan dalam surat Shād (38):58. Quraish Shihab menjelaskan mengenai neraka jahanam, bahwa kata $a z w \bar{a} j$ di sini digunakan untuk menggambarkan macam atau ragam dari siksa itu sangatlah banyak dan seolah-olah bentuknya tidak kalah mengerikan dengan neraka jahanam, bahkan lebih buruk lagi ${ }^{46}$.

Penyebutan lain kata zawj dalam bentuk plural al-azwāj seperti pada ayat,

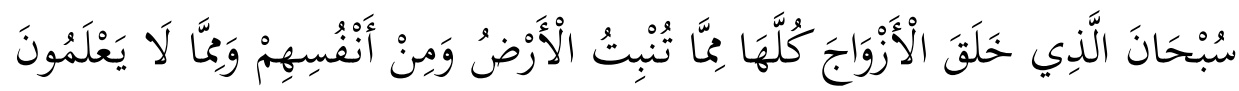

Maha suci Tuhan yang telah menciptakan pasangan-pasangan semuanya, baik dari apa yang ditumbuhkan oleh bumi dan dari diri mereka maupun dari apa yang tidak mereka ketahui. (QS. Yāsīn : 36)

Pada ayat di atas, Ibnu Kathsīr menegaskan penafsiranya terhadap tanda kekuasaan Allah melalui sebuah proses didatangkan rizki bagi manusia. Proses tersebut bermula dari kekuasaan Allah dengan menghidupkan sesuatu yang mati yakni dengan cara menurunkan hujan ke bumi (baca: tanah) kemudian menumbuhkan darinya berbagai macam tanaman melalui biji-bijian yang ditanam pada tanah tersebut, dan dari tanaman tersebut Allah menjadikan sebuah kebun serta mengalirkan air untuk kebutuhan perkembangannya. Dari sini manusia memperoleh rizki berupa hasil kebun yang diciptakan Allah meski telah melalui campur tangan manusia,sebagai usaha untuk memperolehnya ${ }^{47}$.

Dari penjelasan di atas dapat diambil kesimpulan bahwa ayat ini menggambarkan tentang kebesaran dan sebuah kekaguman yang mendalam atas apa yang telah diciptakan

\footnotetext{
${ }^{45}$ Shihab, Tafsir Al-Misbah : Pesan, Kesan Dan Keserasian Al-Qur'an, XII. hlm. 223.

${ }^{46}$ Shihab, Tafsir Al-Misbah: Pesan, Kesan Dan Keserasian Al-Qur'an, XII. hlm. 223.

${ }^{47}$ Ibnu Kasir, Tafsīr Al-Qur'ān Al-'Az̄im, VIII. hlm. 575.
} 


\section{Analisis Semantik Kata Zawj dalam Al-Qur'an Marijatun Hujaz, Nur Huda, dan Syihabuddin Qalyubi Doi: doi.org/10.47454/itqan.v4i2.684}

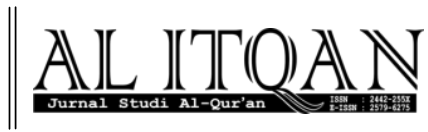

Allah dan kenikmatan yang diperoleh apabila seseorang bersedia mengikuti jalan Allah. Ayat ini turun pada periode al-Qur'an Makkiyah.

Sedangkan pada periode Madinah bisa dikatakan bahwa konteks ayat-ayat zawj dalam al-Qur'an lebih fokus pada pembicaraan rinci hukum-hukum sebagai solusi atas problematika yang dihadapi umat Islam pada saat itu, yakni suatu hal yang menyangkut dengan keberpasangan dalam interaksi sosial, hukum yang berkaitan dengan perkawinan, hukum perwarisan, dan hukum perceraian. Pada ayat-ayat Madaniyyah tidak lagi mengupas tataran Tauhid secara mendetail. Tetapi sudah menambah kepada bagian ilmu syari'at. Kata zawj pada diekspos pada periode Madaniyyah disertai dengan penjelasan ketentuan-ketentuan hukum yang ditujukan bagi kesejahteraan istri-istri. Seperti pada al-Baqarah ayat (2) :240 dan Al-ahzāb (33):50.

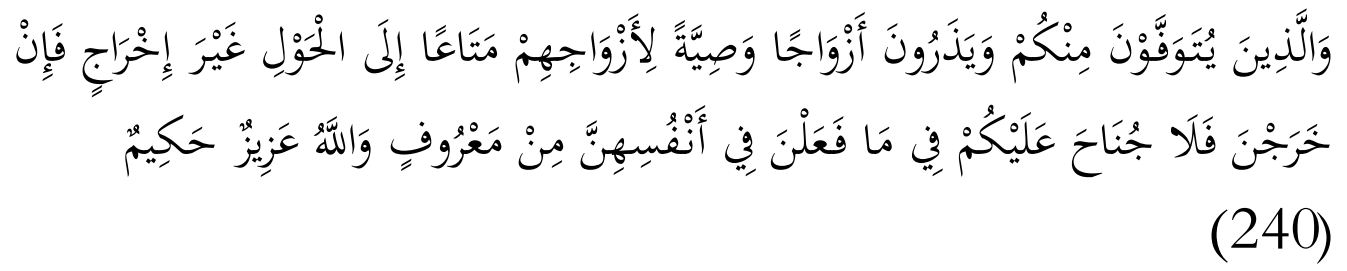

Dan orang-orang yang akan mati di anatara kamu dan meninggalkan istri-istri, hendaklah membuat wasiat untuk istri-istrinya, (yaitu) nafkah sampai setahun tanpa mengeluarkannya (dari rumah), tetapi jika mereka keluar (sendiri), maka tidak ada dosa bagimu (mengenai apa) yang mereka lakukan terhadap diri mereka sendiri dalam hal-hal yang baik. Allah maha perkasa. Maha bijaksana. (QS. al-Baqarah: 240).

Dalam Tafsir al-Misbah ayat ini menjelaskan tentang kewajiban pemberian nafkah oleh ahli waris suami kepada istri yang suaminya meninggal melalui jalan wasiat. Selain nafkah, seorang istri juga berhak menempati rumah tinggal suaminya selama setahun. Ayat ini merupakan pembenaran atas tindakan yang dilakukan Nabi saat ada sebuah keluarga yang berimigrasi dari kota Thaif ke Madinah kemudian meninggal di kota tersebut. Tetapi ada yang berpendapat bahwa ayat ini tidak berlaku lagi karena telah ada ayat yang turun sesudahnya, walaupun ditempatkan dalam surah al-Baqarah (2:234) yang menegaskan dalam bentuk berita yang mengandung perintah tegas bahwa istri-istri yang ditinggal suaminya harus menjalani masa tunggu (iddah) selamat empat bulan sepeuluh hari ${ }^{48}$.

\section{Pasca-Qur'anik}

\footnotetext{
${ }^{48}$ M. Quraish Shihab, Tafsir Al-Misbah: Pesan, Kesan Dan Keserasian Al-Qur'an, Edisi I, (Jakarta: Lentera Hati, 2002), hlm. 629.
} 
Batasan awal sistem periode pasca-Qur'anik adalah setelah konsep al-Qur'an terbentuk secara utuh dengan orientasi telaah secara mendalam terhadap konsep yang dibentuk oleh al-Qur'an. Periode ini dikelompokkan menjadi tiga, yakni periode klasik (6-7 $\mathrm{M})$, periode pertengahan (9-15 M), dan periode modern $(18-21 \mathrm{M})^{49}$.

\section{Periode Klasik}

Tafsir periode ini sering disebut sebagai tafsir periode pertama, yakni era Nabi, sahabat, dan permulaan tabi'in. Era ini ditandai dengan banyaknya sumber periwayatan secara oral. Bisa dikatakan belum banyak tafsir terekspos secara literal(baca: terkodifkasi). Tafsir pada era ini masyhur disebut dengan tafsīr bi al-ma'śü $r^{50}$.

Menurut al-Ṭābarī kata zawjahā pada QS. Al-Nisā’ [4]: $1^{51}$, adalah istri Adam. Hawa diciptakan dari tulang rusuk Adam yang sebelah kiri. Argumen yang dikemukakan berdasarkan ayat bahwa huruf min yang terdapat dalam kalimat wa khalaqa minhā zawjahā merupakan min tab’ḥ̂iyyah yang menunjukkan bahwa Hawa diciptakan dari bagian tubuh Adam. Hal ini juga didasarkan pada hadis Rasulullah saw. riwayat Bukhari dan Muslim, yang menyebutkan secara eksplisit tentang penciptaan Hawa dari tulang rusuk Adam $^{52}$.

\section{Periode Pertengahan}

Tafsir periode ini ditandai dengan spesifikasi aliran-aliran mufasir dan kepentingannya untuk mendukung disiplin ilmu tertentu. Oleh karena itu, produk yang dihasilkan akan memperlihatkan karakteristik mufassir pada masanya ${ }^{53}$.

Dalam konteks ini, kata zawj dalam QS. Al-Nisā' [4]: 1, menurut penafsiran Zamakhsyarī yang dimaksud dengan nafs wähidah adalah ciptaan yang cabangnya sama yaitu diri Adam. Pada frasa wa kholaqa min zawjahā yang termasuk lanjutan dari frasa min nafsin wāhidah terdapat frasa yang dibuang yaitu: min nafsin wāhidah ansya'ahā wa ibtida'ahā wa

\footnotetext{
${ }^{49}$ Saiful Amin Ghofur, Mozaik Mufasir Al-Qur'an Dari Klasik Hingga Kontemporer (Yogyakarta: Kaukaba, 2013), hlm. 16.

${ }^{50}$ Muhammad Sayyid Thanthawi, Ulumul Qur'an Teori Dan Metodologi (Yogyakarta: IRCiSoD, 2013), hlm. 140.

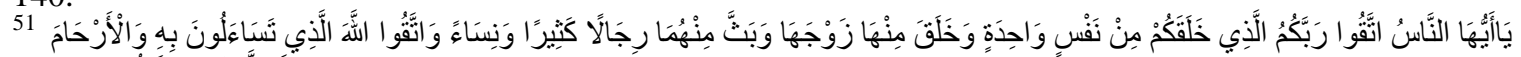

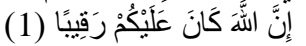

${ }^{52}$ Muhammad bin Jarir Al-Tabari, Jami' Al-Bayan Fi Ta'wil Al-Qur'an, ed. by Ahmag Muhammad Syakir (Beirut: Mu'assasah al-Nasyr al-Islamiy, 2000), vI. hlm. 340.

${ }^{53}$ Ghofur, Mozaik Mufasir Al-Qur'an Dari Klasik Hingga Kontemporer, hlm. 20.
} 


\section{Analisis Semantik Kata Zawj dalam Al-Qur'an Marijatun Hujaz, Nur Huda, dan Syihabuddin Qalyubi Doi: doi.org/10.47454/itqan.v4i2.684}

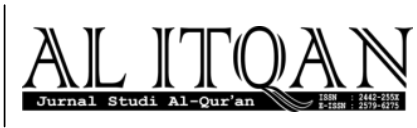

khalaqa minhā zawjahā. Dihapusnya frasa ansha'aha wa ibtida'aha untuk menunjukan makna tersebut, yaitu orang-orang yang berasal dari karakter yang sama, yang diciptakan seorang tersebut dari debu dan terciptanya istri Adam, yaitu hawa dari tulang rusuknya, yang keduanya terjadi perkembangbiakan umat manusia yaitu dua jenis keturunan laki-laki dan perempuan $^{54}$.

\section{Periode Modern}

Periode tafsir ini ditandai dengan adanya istilah tajdìd, yakni upaya untuk menafsirkan al-Qur'an dengan cara menyesuaikan dengan konteks kekinian yang terkait dengan kondisi sosial masyarakat dan perkembangan ilmu pengetahuan ${ }^{55}$. Orientasi penafsiran pada periode ini adalah untuk merekonstruksi produk tafsir-tafsir klasik dengan cara mencari dan menarik relevansinya sesuai konteks kekinian ${ }^{56}$.

Dalam tafsir al-Misbāh surat al-Nisā'(4):1 dijelaskan bahwa konteks ayat ini adalah untuk menjelaskan lahirnya laki-laki dan perempuan yang banyak karena dari seorang ayah yakni Adam dan seorang ibu yakni Hawa yang disesuaikan dengan nafs wahidāh yang dipahami dalam arti ayah manusia seluruhnya. Selanjutnya Quraish Shihab juga menjelaskan kata zawjahā secara harfiah bermakna pasangan yaitu istri Adam yang bernama Hawa. Quraish Shihab menegaskan bahwa Allah menciptakan darinya, yakni dari nafsin wahidāh yang mengandung makna bahwa pasangan suami istri hendaknya menyatu, yakni menyatu dalam hal perasaan dan fikirannya, dalam cita dan harapanya, gerak dan langkahnya, bahkan dalam hal menarik dan menghembuskan nafasnya. Itu sebabnya dalam tafsir al-Misbah kata zawj diartikan sebagai pernikahan (نكاح) yang berarti penyatuan ruhani dan jasmani. Karena suami juga dinamakan (زوج) dan istri pun juga demikian ${ }^{57}$.

Menurut tokoh gender seperti Amina Wadud dan Riffat Hasan kata zawj diartikan sebagai istri, pasangan, jodoh, dan kelompok. secara umum, kata zawj sebagai "pasangan" yang sifatnya hakiki dalam penciptaan dalam kaitanya dengan manusia yang terbentuk dari laki-laki dan perempuan. Karena Allah menciptakan segala sesuatu itu berpasang-pasangan, seperti dalam surat Yāsīn (36):36, (51):49. Tujuan Allah menciptakan manusia adalah supaya

\footnotetext{
${ }^{54}$ Mahmud bin Umar Al-Zamahsyari, Tafsir Al-Kasysyaf, 6th edn (Beirut: Dar Al-Fikr, 1993), I. hlm. 461.

${ }^{55}$ Ahmad Syukri, Metodologi Tafsir Al-Qur'an Kontemporer Dalam P Emikiran Fazlur Rahman (Jambi: Sulton Thaha Press, 2007), hlm. 43.

${ }^{56}$ Rosihan Anwar, Samudra Al-Qur'an (Bandung: Pustaka Setia, 2001). hlm. 282.

${ }^{57}$ M. Quraish Shihab, Tafsir Al-Misbah : Pesan, Kesan Dan Keserasian Al-Qur'an (Jakarta: Lentera Hati, 2002), II. hlm. 331 .
} 
manusia berperan sebagai khalifah (wakil) di muka bumi. Karena manusia dikaruniai kemampuan intelektual, moral, spiritual, dan sosial untuk mengatur bumi ${ }^{58}$.

Singkatnya, katazawj dalam ilmu kesetaran gender dapat diberi makna laki-laki maupun perempuan yang merupakan komponen kemanusiaan yang setara. Karena laki-laki dan perempuan sama-sama memiliki kesetaraan dalam asal-usul dari kemanusiaan. Apa yang membentuk kemanusiaan pada dasarnya menuntut pluralitas manusia, menghargai satu sama lain dan toleransi terhadap perebedaan, dan pasangan suami istri hendaknya menyatu sehingga menjadi diri yang satu yakni menyatu dalam fikiran, cita dan harapnya, dalam gerak dan langkahnya. Itu sebabnya, pernikahan juga disebut dengan zawj. Adapun yang membedakan hanya pada soal pembagian warisan bahwa laki-laki mendapatkan yang lebih karna laki-laki merupakan pemimpin dari nafkah perempuan seperti yang dijelaskan dalam surat al-Nisā [4]: 34.

\section{F. Kesimpulan}

Berdasarkan uraian di atas dapat disimpulkan bahwa kata zawj terdapat di dalam alQur'an dengan 21 bentuk derivasi yang terkandung dalam 72 ayat dari 43 surat dan disebutkan dalam 81 kali dalam al-Qur'an. Makna dasar kata zawj adalah sesuatu yang bukan tunggal atau sesuatu yang memiliki pasangan dan memikili padanan. Makna relasional singtamatik kata zawj dalam al-Qur'an ditemukan ditemukan enam makna, yaitu suami, istri, pasangan, hewan, tumbuhan, dan golongan. Makna relasional paradigmatik kata zawj dalam ranah sinonimitas ditemukan lima kata yang semakna atau berdekatan makna dengan kata zawj, yaitu al-ba'l, al-rijāl, al-mar'ah, al-nisā', dan qarīn. Sementara makna relasional paradigmatik kata zauj dalam ranah antonimitas ditemukan dua makna, yaitu al-fardu dan $a l$ watru.

Makna kata zawj pada masa pra-Qur'anik adalah tipe permadani yang direpresentasikan pada wanita zaman jahili yang berfungsi untuk melindungi sengatan matahari. Kata zawjpada masa Qur'anik terbagi menjadi dua. Periode Mekkah menggambarkan tentang terhadap tanda kebesaran Allah dan kenikmatan yang akan di dapat apabila seseorang bersedia mengikuti sejalan dengan Islam. Pada periode Madinah kata zawj lebih mengarah kepada hukum-hukum dalam keberpasangan dalam interaksi sosial seperti hukum tentang pembagian warisan. Pada periode pasca-Qur'anik makna kata zawj terbagi

\footnotetext{
${ }^{58}$ Etin Anwar, Jati Diri Perempuan Dalam Islam (Bandung: Mizan Pustaka, 2017), hlm. 150.
} 
Analisis Semantik Kata Zawj dalam Al-Qur'an Marijatun Hujaz, Nur Huda, dan Syihabuddin Qalyubi

Doi: doi.org/10.47454/itqan.v4i2.684

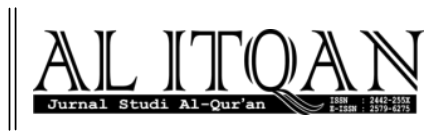

menjadi tiga periode. Pada periode klasik, kata zawj lebih menitikberatkan pada makna (penciptaan) istri (Hawa) yang berasal dari tulang rusuk nabi Adam. Pada periode pertengahan terdapat sedikit pergeseran makna, terciptanya pasangan atau manusia jenis lakilaki dan perempuan berasal dari Adam dan Hawa yang saling berkaitan satu sama lain. Sementara makna kata zawj padan periode modern lebih berkembang menjadi disiplin ilmu baru yaitu ilmu kesetaraan gender antara laki-laki dalam perempuan. perempuan dan laki-laki (pasangan) merupakan komponen atau ciptaan yang sama sehingga bisa terjadi keberlangsungan hidup yang harmonis yaitu keberpasangan dalam bentuk pernikahan. ketiga periode ini menghasilkan makna sinkronik kata zawj yang tetap melekat yakni pasangan. 


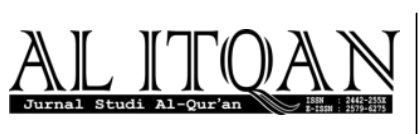

Analisis Semantik Kata Zawj dalam Al-Qur'an

Marijatun Hujaz, Nur Huda, dan Syihabuddin Qalyubi

Doi: doi.org/10.47454/itqan.v4i2.684

\section{DAFTAR PUSTAKA}

Al-Amirī, Labīb bin Rabi'ah. Diwān Labīb Bin Rabiah Al-Amirī, Mesir: Dar al-Ma'rifah, 2004.

Al-Askarī, Abū Hilāl. Mu’jam Al-Furuq Al-Lughawiyah (Damaskus: Mu'assasah al-Nashr alIslāmiy, 2000)

Al-Ṭabarī, Muhammad bin Jarir, Jami' Al-Bayān fì Ta'wil Ay Al-Qur'an. ed. Ahmad Muhammad Syakir. Beirut: Mu’assasah al-Risālah, 2000.

Al-Zamaḥsharī, Mahmud bin Umar, Tafsīr Al-Kashshāf. Beirut: Dar Al-Fikr, 1993.

Almirzanah, Syafaatun. Pemikiran Hermeneutika Dalam Tradisi Islam: Reader. Yogyakarta: Lembaga Penelitian, Universitas Islam Negeri Sunan Kalijaga, 2011.

Anwar, Etin. Jati Diri Perempuan Dalam Islam. Bandung: Mizan Pustaka, 2017.

Anwar, Rosihan. Samudra Al-Qur'an. Bandung: Pustaka Setia, 2001.

Asy’ari, Hasyim, “Keistimewaan Bahasa Arab Sebagai Bahasa Al-Qur'an”, Nidhomul Haq: Jurnal Manajemen Pendidikan Islam, Vol.1, No.1 (2016).

Bunyamin, Bachrum dan Salad, Hamday. Syair-Syair Arab Pra Islam: Al-Muallaqāt. Yogyakarta: Gading Pustaka, 2017.

Ibrahim, Musthafa. dkk. Al-Mu’jam Al-Wasīt. Istambul: Al-Maktabah Al-Islamiyyah, 1999. Fachrudin, Aziz Anwar. Pengantar Sejarah Dan Mazhab Linguistik Arab. Sidoarjo: CV. Lisan Arabic, 2017.

Faris, Ahmad bin. Mu'jam Maqayis Al-Lughah, ed. Abdus Salam Muhammad Harun. Beirut: Dar Al-Fikr, 1979.

Ghofur, Saiful Amin. Mozaik Mufasir Al-Qur'an Dari Klasik Hingga Kontemporer. Yogyakarta: Kaukaba, 2013.

Gusmian, Islah. Khazanah Tafsir Indonesia. Jakarta: Teraju, 2003.

Ismail, Ecep. 'Analisis Semantik Pada Kata Ahzāb Dan Derivasinya Dalam Al-Quran'. AlBayan: Jurnal Studi Ilmu Al-Qur'an Dan Tafsir, vol. 1. no. 2(2016).

Izutsu, Toshihiko, Relasi Tuhan Dan Manusia Pendekatan Semantik Terhadap Al-Qur'an, Terj, Agus Fahri Husein Dkk. Yogyakarta: Tiara Wacana, 2003.

\section{AL-ITQAN, Volume 4, No. 2, 2018}




\section{Analisis Semantik Kata Zawj dalam Al-Qur'an Marijatun Hujaz, Nur Huda, dan Syihabuddin Qalyubi Doi: doi.org/10.47454/itqan.v4i2.684}

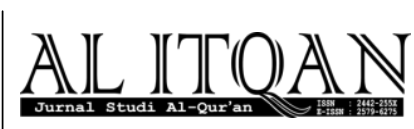

Kathīr, Muhammad bin Umar bin, Tafsìr Al-Qur'an al-'Ażīm. Beirut: Dar Al-Tayyibah, 1999.

Mahsun, M.S, Metode Penelitian Bahasa Metode Penelitian Bahasa: Tahapan Strategi Metode Dan Tekniknya. Jakarta: Raja Grafindo Persada, 2014.

Manzur, Muhammad bin Mukrim bin, Lisān Al-'Arb. Beirut: Dar Shadir, th.

Matson, Ingrid. Ulumul Qur'an Zaman Kita. Jakarta: Zaman, 2013.

Moleong, Lexy J. Metode Penelitian Kualitatif. Bandung: Remaja Rosdakarya, 2014.

Mujahid, Ahmad. 'Makna Sinkronik-Diakronik Kata 'Usr Dan Yusr Dalam Surat AlInsyirāh', Relegia Jurnal Ilmu-Ilmu Keislaman, vol. 22, no.1 (2019),

Shihab, M. Quraish. Tafsir Al-Misbah: Pesan, Kesan Dan Keserasian Al-Qur'an. Jakarta: Lentera Hati, 2002.

Subhan, Zaitunah. Al-Qur'an Dan Perempuan : Menuju Kesetaraan Gender Dalam Penafsiran. Jakarta: Kencana Prenada Media Group, 2015.

Syukri, Ahmad. Metodologi Tafsir Al-Qur'an Kontemporer Dalam Pemikiran Fazlur Rahman. Jambi: Sulton Thaha Press, 2007.

Thanthawi, Muhammad Sayyid. Ulumul Qur'an Teori Dan Metodologi. Yogyakarta: IRCiSoD, 2013.

Umar, Nasaruddin. Argumen Kesetaraan Gender Dalam Al-Qur'an. Jakarta: Paramadina, 2001 
